Studia nad Autorytaryzmem i Totalitaryzmem 43, nr 4 Wrocław 2021

https://doi.org/10.19195/2300-7249.43.4.7

\author{
MARIA KACZOROWSKA \\ ORCID: 0000-0001-8301-5774 \\ Uniwersytet Wrocławski \\ e-mail: maria.kaczorowska@uwr.edu.pl
}

\title{
Land and mortgage registers as a cornerstone of real estate transactions in Polish law - a historical and legal outline (On the 40th anniversary of the enactment of the Land and Mortgage Registers and Mortgage Act)
}

\begin{abstract}
With its core purpose of establishing the legal status of immovable property, the system of land and mortgage registers (perpetual books) operating in Poland plays a paramount social and economic role in ensuring legal security of real estate conveyancing, and thereby contributes to implementing the constitutional principle of democratic state ruled by law. The foundations for a uniform land and mortgage register law were laid down in the 1930s by the Codification Commission of the Republic of Poland, appointed after the Polish State regained independence in 1918, following the period of partitions. The works of the Commission were interrupted by the outbreak of the Second World War in 1939. In the early years of the post-war communist regime, the Commission's draft provisions on land and mortgage registers served as the basis of the unified legislation that entered into force. Shortly thereafter, however, the very usefulness of the institution of land and mortgage register was contested by communist authorities, as it was considered contrary to the ideological assumptions underlying the socialist system. As a consequence, although not abolished, the land and mortgage register law's relevance was diminished substantially for several decades, as manifested by the fact that it was not incorporated into the Civil Code of 1964 . The significance of land and mortgage registers was restored to a certain degree only upon adopting the Land and Mortgage Registers and Mortgage Act of 1982, which, after being appropriately amended, is still in force. Subsequently, land and mortgage registers were subject to systemic reforms as part of the democratic transition process in Poland, and in recent years, advanced computerisation and informatisation actions have been undertaken bringing about noteworthy modernisation effects.

In view of the forthcoming 40th anniversary of the enactment of the Land and Mortgage Registers and Mortgage Act, it is worth providing deeper insights into contemporary Polish land and mortgage register law against the historical background. The article is aimed at outlining the evolution
\end{abstract}


of legislative and doctrinal approaches to the position of land and mortgage registers in the legal system in Poland - from the period of the interwar Codification Commission's activity, through the decades of the totalitarian domination of the communist system, until the present time. In this respect, particular reference will be made to basic rules underpinning the organisation of land and mortgage registers. Based on the overview of the development of land and mortgage register law, with special consideration of its legislative marginalisation in the People's Republic of Poland, conclusions will be drawn as to the current legal position of land and mortgage registers in the context of recognising the vital importance thereof for property law relations.

Keywords: land and mortgage registers, Poland, Codification Commission of the Republic of Poland's draft of the Property Law, marginalisation of land and mortgage register law in the communist period, Land and Mortgage Registers and Mortgage Act of 1982.

\section{Introduction}

The process of land registration, the general aim of which is to record the transfer and creation of interests in land, serves crucial functions in the national economic and social development because it guarantees legal security of real estate transactions as well as mortgage lending. Historically, a variety of models of land registers have evolved in individual jurisdictions across the world. The Polish land and mortgage register (verbatim: perpetual book - ksiega wieczysta ${ }^{1}$ ) is categorised as a specific type of Central European land register. ${ }^{2}$

It should be highlighted that, in contrast to countries of Western Europe, because of its tragic historical background, Poland was prevented from freely developing various areas of social and economic life in the course of the 20th century. This is also the case with regard to the formation of the system of land and mortgage registers.

In 1918, the Polish State regained independence after 123 years of partitioning by Russia, Prussia and Austria, which opened the period of the Second Republic of Poland. ${ }^{3}$ It was made possible following the fall of the three annexing

1 The terms 'land and mortgage register' and 'perpetual book' are used interchangeably in the text.

2 On different types of land registers existing in Europe, see further e.g. P. Blajer, Rejestry nieruchomości. Studium prawnoporównawcze, Warszawa 2018, pp. 8, 19 ff.; T. Stawecki, "Rejestry nieruchomości, księgi hipoteczne i księgi wieczyste od czasów najdawniejszych do XXI wieku", Studia Iuridica 40, 2002, pp. 167-208; S. Rudnicki, "Systemy ksiąg wieczystych i zabezpieczeń majątkowych na nieruchomościach w większości krajów europejskich", Rejent 1995, no. 11, pp. 27-39; S. Cámara Lapuente, "Registration of interests as a formality of contracts: Comparative remarks on land registers within the frame of European private law", European Review of Private Law 2005, no. 6 , pp. 831-837.

3 See e.g. A. Chwalba, "Państwo, społeczeństwo, naród", [in:] Encyklopedia historyczna świata, vol. 14. Polska, ed. A. Chwalba, Kraków 2003, pp. 29-30; P. Szlanta, Polish Roads to Independence, https://niepodlegla.gov.pl/en/about-niepodlegla/polish-roads-to-independence/ (accessed: 27.09.2021). 
empires as a result of the First World War, as well as the joint efforts of Poles, who soon afterwards also managed to defend their newly-restored sovereignty during the Polish-Soviet War. What deserves to be particularly emphasised is the significance of the famous victory achieved by the Polish army at the 1920 Battle of Warsaw, described as the 'Miracle of the Vistula,' which stopped the spread of the communist revolution to Western Europe. ${ }^{4}$ Given the differentiation of legal systems inherited from the three invaders, the legislature of the reborn Poland faced a challenging task of unifying the law. Already in 1919, the Codification Commission of the Republic of Poland (Komisja Kodyfikacyjna Rzeczypospolitej Polskiej) was appointed and was entrusted with preparing, first of all, uniform civil and penal legislation throughout the country. The output of the Commission included, i.a., a draft of property law, elaborated in the 1930s, which provided for provisions on land and mortgage registers. The works on the draft, however, were not completed because of the outbreak of the Second World War. Not only was Poland tragically invaded by joint German and Soviet aggression in September $1939,{ }^{5}$ which led to the extermination of Polish citizens, war crimes and extensive devastation of the country by the two occupiers, but also, despite Polish soldiers' heroic fight on all fronts of the war on the side of the Allies, it did not regain full independence after the war. Following the decisions made by the 'Big Three' leaders at the Yalta Conference in 1945, Polish borders were entirely redrawn and the Polish State fell under the Union of Soviet Socialist Republics (USSR) domination, becoming the scene of subsequent persecution and crimes against Polish patriots. ${ }^{6}$

Under the conditions of the communist totalitarian regime, the post-war law implemented in Poland was subordinated to the imposed socialist ideology. With regard to land and mortgage register law, even though in the initial period after the war the draft provisions prepared by the Codification Commission were utilised as the basis of the unified legislation, not long thereafter, land and mortgage registers were marginalised, since their usefulness for the socialist system was called into question. It was decided that they would be temporary, as it would be the case of individual ownership of land. Eventually, despite the doctrinal demands for the abolition of the institution of land and mortgage register, the relevant provisions remained in force, which was largely determined by public resistance. Nevertheless, they were not incorporated into the Civil Code enacted in 1964.

${ }^{4}$ See e.g. M. Szumiło, Battle of Warsaw 1920, https://ipn.gov.pl/en/digital-resources/articles/4397,Battle-of-Warsaw-1920.html (accessed: 27.09.2021); E.V. D'Abernon, The Eighteenth Decisive Battle of the World: Warsaw, 1920, London 1931.

5 In consequence of a secret German-Soviet pact signed on 23 August 1939, called the Ribbentrop-Molotov Pact, Poland was invaded by Germany on 1 September 1939, and by the Soviet Union on 17 September 1939. See e.g. A. Chwalba, op. cit., pp. 32-33.

${ }^{6}$ See e.g. M. Korkuć, The Fighting Republic of Poland 1939-1945, Warszawa 2019. 
It was not until the early 1980s that the legal significance of land and mortgage registers was restored to some extent upon adopting the Land and Mortgage Registers and Mortgage Act of 6 July $1982^{7}$ (ustawa o ksiegach wieczystych i hipotece, hereinafter referred to as: LMRMA), whose provisions, after being appropriately amended, continue to apply today as the statutory basis for the functioning of land and mortgage registers. Following the formal collapse of communism in 1989, in the period of democratic transition in Poland, systemic reforms of land and mortgage registers were implemented, including those connected with computerisation and informatisation. Currently, Polish land and mortgage registers operate electronically and are subject to further modernisation.

The year 2022 will mark the 40th anniversary of the enactment of LMRMA. This provides an opportunity to inquire into the course of development of the land and mortgage register law provisions and accentuate the specificity of the Polish land registration system. The central focus of the article is on discussing in a synthetic manner the basic assumptions underlying the model of land and mortgage register, with special reference to its organisational dimension, in the context of the changing legislative and doctrinal attitudes towards the status of land and mortgage registers in the legal system over the subsequent periods of the 20th century history of Poland and modern times. Particular attention shall be paid to the factors that determined the failure of the attempts to eliminate land and mortgage register law from the Polish legislation in the communist period, and allowed LMRMA to be adopted in the early 1980s. Against this background, an assessment will be made of the current directions of development of the system of land and mortgage registers and new legislative tendencies in this respect.

\section{General characteristics of land and mortgage registers}

The land and mortgage register is a public register into which titles to land and encumbrances thereon are entered. As follows from art. 1 para. 1 LMRMA, the basic purpose of keeping land and mortgage registers is to establish the legal status of land (immovable property). This rule corresponds to the main functions attributed to land and mortgage registers, i.e. the information function (consisting in reducing uncertainty as to the legal status of land by providing specific and complete land information), the protective function (which ensures the accuracy of information that can be relied on by persons acting in trust to the content of the land and mortgage register), and the control function (relating to the power of the land registration authority to check the legality of circumstances to be disclosed in the land and mortgage register). ${ }^{8}$ The first two functions are connected with the

7 Consolidated text: Journal of Laws (Dz.U.) of 2019, Item 2204, as amended.

${ }^{8}$ See e.g. J. Kuropatwiński, [in:] Ustawa o księgach wieczystych i hipotece. Komentarz, eds. M. Habdas, M. Fras, Warszawa 2021, pp. 39 ff.; M. Deneka, Księgi wieczyste. Zasady materialno- 
principle of publicity, being one of the key organisational principles underlying land and mortgage registers. Publicity may be considered in formal and substantive aspects. In formal terms, it refers to the accessibility of information from land and mortgage registers, whereas substantive publicity is based on the assumption that the land and mortgage register reflects the actual status of land, and it thus can be considered reliable.

As already mentioned, the land and mortgage register, being largely based on solutions deriving from German law, shares most of the features with the Central European land register - the land book, or rather, ground book (ksiega gruntowa, Grundbuch). What the classical land book and the Polish perpetual book have in common is that in both cases, the register is kept by a court within non-contentious jurisdiction; the subject of registration are rights and the register follows the real system (real folium), which means that it is organised on the basis of immovable properties; good faith in the register's content is protected, and the register is structured in a specific manner (consisting of distinct parts, which regard, respectively, the description of immovable property, the owner, and finally the restrictions, securities and other limited rights). The main difference, in turn, concerns legal effects of registration - as for the land and mortgage register, in principle, the entry therein is declaratory and not constitutive, which is the rule under German law. ${ }^{9}$ It is therefore worth stressing that the subtype of the Central European land register that has evolved in Poland presents important specificities developed by Polish legal thought, offering an alternative to the classical model. ${ }^{10}$

What additionally emphasises the originality of the institution of land and mortgage register is the unique term 'perpetual book,' used in Polish language. This denomination refers to the Polish legal tradition, and expresses the quality of durability of land and mortgage registers in the sense that their records shall not ever be subject to destruction, even if they are closed. ${ }^{11}$ Thereby, the substantial role land and mortgage registers play in guaranteeing security of real estate conveyancing is highlighted.

prawne, Warszawa 2012, pp. 23 ff.; T. Stawecki, Rejestry publiczne. Funkcje instytucji, Warszawa 2005, pp. 34 ff., 303; J. Skąpski, "Funkcja ksiąg wieczystych", [in:] Prace z prawa cywilnego wydane dla uczczenia pracy naukowej Józefa Stanisława Piątowskiego, eds. B. Kordasiewicz, E. Łętowska, Wrocław 1985, pp. 117 ff. Cf. R. Moszyński, L. Policha, A. Izdebska, Księgi wieczyste, Warszawa 1960, pp. 21-22.

${ }^{9}$ See e.g. J. Kuropatwiński, Księgi wieczyste. Komentarz do art. $1-58^{2}$ u.k.w.h. oraz art. $626^{1}$ $-626^{13}$ k.p.c., vol. 1. Komentarz do art. 1-10 ustawy o ksiegach wieczystych i hipotece, Bydgoszcz 2013, pp. 24-25; P. Blajer, op. cit.; B. Zdziennicki, "Regulacja prawna ksiąg wieczystych", Studia Prawnicze 2001, no. 2, pp. 8 ff.; S. Cámara Lapuente, op. cit., pp. 833-834.

10 J. Kuropatwiński, Księgi wieczyste..., p. 59.

11 J. Pisuliński, [in:] Ustawa o księgach wieczystych i hipotece. Postepowanie wieczystoksięgowe, ed. J. Pisuliński, Warszawa 2014, pp. 31-32; J. Ignatowicz, K. Stefaniuk, Prawo rzeczowe, Warszawa 2012, p. 350. 


\section{Stages of the formation of land and mortgage register law in Poland. An overview}

Before embarking on discussing the course of development of the legislation on land and mortgage registers during the period of the Second Republic of Poland and then the communist period, it is worth underlining that the origins of legal solutions aimed to collect and publicise information on property law relations regarding land in the Polish territories date back to the Middle Ages. At that time, real estate transactions were recorded in a chronological order in land and castle court books (ksieggi sadowe ziemskie i grodzkie). Upon entry in the relevant court book, a juridical act was considered to assume the quality of 'perpetuity' (wieczystość). Of key importance for the development of legal rules relating to recordation of real estate transactions was the Act on the Validity of Records (ustawa o ważności zapisów) of 1588 , which provided a foundation for modern mortgage law. What particularly proves the pioneering character of the above Act is that it introduced the principle of publicity of mortgage, thus surpassing Western European legislations. ${ }^{12}$

Unfortunately, further reforms aimed at improvement of registration procedure by establishing separate books for each immovable property had failed to be implemented before the downfall of the Polish-Lithuanian Commonwealth (the First Republic of Poland) as a result of the division of its territories among the three empires of Russia, Prussia and Austria, which took place at the end of the 18th century. In individual partition areas, different rules governing land registration applied. ${ }^{13}$ With respect to territories incorporated into Prussia and Austria, Polish regulations in force at that time were repealed and replaced by legislations of respective partitioning states. Under Prussian and Austrian laws, the system of land books had developed. ${ }^{14}$ In the Russian partition area, at the initial stage, the existing Polish law retained its force. After the establishment of the Kingdom of Poland (the 'Congress Kingdom,' created by the Vienna Congress in 1815 and subsequently forcibly integrated with the Russian Empire), the system of mortgage registers (ksiegi hipoteczne) was adopted by virtue of the Mortgage Act (ustawa hipotec$z n a)$ of $1818,{ }^{15}$ considered a monument of Polish legislation. ${ }^{16}$ The provisions of

12 See e.g. T. Maciejewski, Historia ustroju i prawa sądowego Polski, Warszawa 2017, pp. 93, 107, 138-139; W. Wójcikiewicz, Prawo hipoteczne Królestwa Polskiego, Wrocław 1967, pp. 16 ff.; W. Dajczak, "Historical development of private law in Poland", [in:] Foundations of Law: The Polish Perspective, eds. W. Dajczak, T. Nieborak, P. Wiliński, Warszawa 2021, p. 57.

13 See further e.g. J. Kuropatwiński, Ksiegi wieczyste..., pp. 54-55.

14 See further e.g. P. Blajer, "Z historii ksiąg gruntowych (Grundbücher)”, Studia Prawnicze. Rozprawy i Materiaty 2015, no. 2, pp. $77 \mathrm{ff}$.

15 Act of 26 April 1818 - Law on the Determination of Ownership of Real Estate, Privileges and Mortgages in Place of Title XVIII of Book III of the Civil Code (Journal of Laws of the Kingdom of Poland of 1818, vol. 5, no. 21).

16 See e.g. W. Wójcikiewicz, op. cit., pp. 53 ff.; J. Glass, Zarys prawa hipotecznego w b. Królestwie Polskiem, Warszawa-Kraków 1921, p. VIII; L. Domański, "O istocie i znaczeniu Ustawy hipotecznej roku 1818-go”, Gazeta Sądowa Warszawska 1918, no. 43-45, pp. 422-423. 
that Act combined legal solutions existing under the former Polish law, and Prussian law as well as French law. Mortgage registers were established for each immovable property, and consisted of three parts: the register of perpetual contracts, the collection of documents and the mortgage register. It was mortgage offices (kancelarie hipoteczne), headed by mortgage registrars (pisarze hipoteczni), that were in charge of keeping mortgage registers. ${ }^{17}$

\subsection{The concept of land and mortgage register in the Codification Commission of the Republic of Poland's unification works}

The reconstruction of the Polish State, which reappeared on the map of Europe on 11 November 1918, required that the diversity of partitioning countries' legislations remaining in force in individual provinces be removed as rapidly as possible. For that purpose, the Codification Commission of the Republic of Poland was established by virtue of the Act of 3 June 1919 on the Codification Commission (ustawa o komisji kodyfikacyjnej), ${ }^{18}$ adopted by the Legislative Sejm (Sejm Ustawodawczy) only a few months after the day of regaining independence. The Commission consisted of eminent representatives of Polish legal scholarship and practice, appointed by the Head of State, and later by the President of the Republic of Poland. ${ }^{19}$ The Commission's members dedicated themselves to a demanding and complex work of creating from scratch a new Polish legal system by way of unification and, subsequently, codification of various fields of law, including civil law. At the very beginning of the Civil Law Section's activity, the possibility of adopting any of foreign civil codes in force up to then was rejected. It was intended that an entirely new code, adapted to the Polish nation's intrinsic

17 See further e.g. M.A. Dalkowska, "Geneza oraz kształt prawa hipotecznego na ziemiach polskich w XIX w.”, Przeglad Ustawodawstwa Gospodarczego 2019, no. 3, pp. 50-54; T. Maciejewski, op. cit., pp. 266-268; P. Sławicki, "Mortgage registers and mortgage council in the Kingdom of Poland", Miscellanea Historico-Iuridica 12, 2013, pp. 135-144.

18 Journal of Laws of the Polish State No. 44, Item 315.

19 See further e.g. L. Górnicki, "Komisja Kodyfikacyjna II RP: pozycja ustrojowa, struktura organizacyjna, podejmowanie decyzji”, Prawo 328, 2019, pp. 109-151; J. Markiewicz, "Kształtowanie się polskiego systemu prawa sądowego i jego twórcy w okresie międzywojennym 1919-1939 (Wybrane zagadnienia)", Teka Komisji Prawniczej — Oddziat Lubelski PAN 3, 2010, pp. 113-122; M. Mazuryk, I. Sadowski, "Organizacja i funkcjonowanie komisji kodyfikacyjnych prawa cywilnego w latach 1919-1989. Zarys problematyki”, Roczniki Nauk Prawnych 23, 2013, no. 1, pp. 8-13; S. Grodziski, "Prace nad kodyfikacją i unifikacją polskiego prawa prywatnego (1919-1947)", Kwartalnik Prawa Prywatnego 1992, no. 1-4, pp. 9-19; D. Malec, "Ustrój i prawo XX w.", [in:] Encyklopedia historyczna świata, vol. 14. Polska, pp. 70-73; S. Golab, "The codification of Polish Law", Journal of Comparative Legislation and International Law 6, 1924, no. 1, pp. 95-109; W. Dajczak, op. cit., pp. 50-51; M. Gałędek, "The beginning of the debate on the codification of Polish law after the World War I: The issue of the Codification Commission autonomy in the light of political declarations", Studia Iuridica 80, 2019, pp. 119-134; E.M. Guzik-Makaruk, P. Fiedorczyk, "The achievements of the Codification Commission of the Second Republic of Poland - a century after regaining the independence", Internal Security 2018, special issue, pp. 17-28. 
needs and conforming to the standards of the modern legal culture, should be created. ${ }^{20}$ Separate drafts pertaining to each field of law covered by the civil code were being elaborated in parallel by designated reporters, and subsequently submitted to relevant sub-commissions for deliberation. Once adopted at first reading by a sub-commission, a given draft was subject to extensive consultation by other members of the Codification Commission, courts, competent authorities and organisations. Based on the opinions obtained, the draft was passed through second reading by the sub-commission, then adopted by a special college, and finally submitted to the Minister of Justice in order to pursue the legislative procedure. ${ }^{21}$

Although the Codification Commission's extensive works conducted in the years 1919-1939 did not result in preparing a complete draft of a civil code, their outcomes are undoubtedly a remarkable lawmaking achievement recognised internationally. Among the principal legal enactments of the interwar period, two 1933 codes should be mentioned: the Code of Obligations, considered the most distinguished accomplishment of private law doctrine on a European scale, and the Commercial Code. Representing the highest legislative level and practical viability, both the above codes crucially influenced the development of future Polish legislation and legal scholarship. ${ }^{22}$

As regards property law, the unification process posed much more difficulties than in case of other domains of civil law, such as the law of obligations or commercial law, owing to a lasting nature of property law relations and the fact that until then applicable specific property law constructs had been well-established in the social awareness. ${ }^{23}$ The Codification Commission's works started in 1929, with mortgage law being given priority, due to an urgent need to unify the forms of mortgage credit. In 1933, it was decided not to continue preparing a separate mortgage act, and instead to move to elaborate a draft regarding property law as a whole. A complete draft in the first reading version, including rules on land and mortgage registers, was published on 14 July $1937^{24}$ and subject to public discussion. ${ }^{25}$ The draft (hereinafter referred to as: the draft of the Property Law of 1937) was an important contribution to the Polish legal doctrine, which not only

${ }^{20}$ L. Górnicki, Prawo cywilne w pracach Komisji Kodyfikacyjnej Rzeczypospolitej Polskiej w latach 1919-1939, Wrocław 2000, p. 114.

21 S. Grodziski, op. cit., p. 13; T. Maciejewski, op. cit., pp. 345-346.

22 See e.g. L. Górnicki, Prawo cywilne w pracach..., pp. 455-462; J. Markiewicz, op. cit., pp. 118-120; J. Kola, "Działalność Komisji Kodyfikacyjnej RP w obszarze prawa zobowiązań. Refleksje z okazji 80. rocznicy kodeksu zobowiązań”, Palestra 2013, no. 9-10, pp. 250-60; E.M. Guzik-Makaruk, P. Fiedorczyk, op. cit., pp. 21-22.

23 See e.g. J. Kuropatwiński, Księgi wieczyste..., p. 55.

24 Projekt prawa rzeczowego uchwalony w pierwszym czytaniu przez Podkomisję Prawa Rzeczowego Komisji Kodyfikacyjnej, Warszawa 1937.

${ }^{25}$ S. Grodziski, op. cit., p. 18; Projekt prawa rzeczowego..., pp. 3-4; J. Górski, "O projekcie prawa rzeczowego", Ruch Prawniczy, Ekonomiczny i Socjologiczny 1938, no. 1, pp. 22-28. 
drew from foreign legislations, but also introduced many innovative solutions, thus proving its originality. ${ }^{26}$

Initially, however, distinct provisions on 'land books' (ksiegi ziemskie) were proposed. ${ }^{27}$ As stated in the preparatory reports of 1930 and 1931, terminologically, it was considered inappropriate to use either the designation 'mortgage registers' - ksieggi hipoteczne (because of its limited scope, covering only the mortgagee's rights, but not other rights entered in the register, such as ownership and servitudes) - or the name 'perpetual books' - ksiegi wieczyste (because of the entries in the register being by their nature subject to changes over time, and thus in any case not perpetual) for land and mortgage registers. Therefore, it was the term 'land' (ziemski) that became the preferred option, as it referred to the historical tradition; nevertheless, the alternative term 'ground' (gruntowy) was also found acceptable. ${ }^{28}$

By contrast, under the abovementioned draft of Property Law of 1937, land and mortgage registers were denominated literally as 'perpetual books' (ksieggi wieczyste). Such a choice was motivated by the common use of that term in legal language, a reference to the tradition of the ancient Polish law as well as the conviction that it adequately reflected the nature of land and mortgage registers. At the same time, the members of the Codification Commission recognised that the name 'ground books' (ksiegi gruntowe) should be rejected as a germanism, all the more so because the term 'ground' (grunt) itself did not occur in the text of the draft. Again, the alternative option, i.e. the name 'mortgage registers' (księgi hipoteczne), was excluded for the reason of its scope being too narrow. ${ }^{29}$

The proposed provisions on land and mortgage registers were contained in Title VII of the draft of the Property Law of 1937, encompassing two sections, devoted to the organisation of land and mortgage registers (ustrój ksiag wieczystych) and the general provisions on rights evidenced in the land and mortgage register (przepisy ogólne o prawach jawnych z księgi wieczystej), respectively. Among the organisational aspects of the functioning of land and mortgage registers addressed in the draft were: the setting up of land and mortgage registers, entries, mortgage letters as well as the competence of authorities and the proceedings.

26 J. Górski, op. cit., pp. 27-28. See further e.g. L. Górnicki, "Prawa rzeczowe", [in:] Synteza prawa polskiego 1918-1939, eds. T. Guz, M.R. Pałubska, J. Głuchowski, Warszawa 2013, pp. 300-353.

27 F. Zoll, Referat przygotowawczy do prac nad skodyfikowaniem jednolitego prawa ksiag ziemskich (ksiag hipotecznych, gruntowych, wieczystych), obejmujacy głównie zarysy projektu ustawy z objaśnieniami, Warszawa 1930; idem, Drugi referat przygotowawczy do prac nad skodyfikowaniem jednolitego prawa ksiag ziemskich (ksiag hipotecznych, gruntowych, wieczystych), obejmujacy zestawienie tez, które maja być podstawa projektu ustawy, Warszawa 1931.

28 F. Zoll, Referat przygotowawczy..., pp. 24-26; idem, Drugi referat przygotowawczy..., p. 5.

29 See e.g. J. Wasilkowski, "Zasady ustroju ksiąg wieczystych w projekcie prawa rzeczowego", Przeglad Notarialny 1937, no. 13-14, p. 285; J. Kuropatwiński, Księgi wieczyste..., pp. 27-28; J. Pisuliński, op. cit., pp. 31-32. 
As provided for in draft art. 338, land and mortgage registers should serve to disclose proprietary rights on immovable property and to make other entries specified by law. It was obligatory to set up land and mortgage registers for any immovable property, subject to the exceptions laid down in further provisions (draft art. 339). Each single immovable property should have a separate land and mortgage register kept for it (draft art. 342). According to draft arts. 344-346, the land and mortgage registers should consist of four sections. The first should contain the designation of immovable property, based on cadastral data or other official measurements; the second should contain the designation of the owner, the title of acquisition and the limitations in the owner's capacity to legal actions; the third should be intended for entries concerning servitudes, real burdens and limitations in disposal of immovable property, as well as for entries concerning personal rights whose disclosure was provided for by law; and the fourth should be intended for entries concerning mortgages and limitations in the mortgagee's capacity to legal actions. Pursuant to draft art. 347, a collection of documents, consisting of original and authenticated copies of documents being the basis for entry, should be kept for each land and mortgage register. ${ }^{30}$

Moreover, the draft of the Property Law of 1937 gave expression to the principle of publicity of land and mortgage registers, - in both its formal and substantive aspects. Pursuant to draft art. 348, land and mortgage registers should be freely accessible. Anyone should be entitled to consult land and mortgage registers and collections of documents, subject to relevant order regulations. As laid down in art. 392, no one might plead ignorance of entries in a land and mortgage register, nor of applications which had been noted therein. ${ }^{31}$

Unless otherwise provided by law, an entry might be made only on the basis of a public document. In particular, a juridical act to be the basis for entry should be effected in the form of a notarial deed, even if that form was not required for the validity of the declaration of will (draft art. 353). As a general rule, entries in the land and mortgage register should be made only upon submission of an application (draft art. 354). ${ }^{32}$

As followed from draft art. 369, the keeping of land and mortgage registers should belong to the competence of municipal courts (sady grodzkie). It also was envisaged that land and mortgage registers should be kept by a judge, and the activities that could be performed independently by court clerks (sekretarze sadowi) should be determined by the Minister of Justice by way of a regulation (art. 371). ${ }^{33}$

Additionally, referring briefly to some substantive principles of land and mortgage registers stipulated in the draft of the Property Law of 1937, it should be indicted that, as a rule, an entry in the land and mortgage register was required for

30 See J. Wasilkowski, op. cit., p. 286; J. Górski, op. cit., p. 26.

31 See J. Wasilkowski, op. cit., pp. 286-287.

32 See ibidem, p. 287.

33 See ibidem, p. 286; J. Górski, op. cit., pp. 26-27. 
the acquisition of proprietary rights on immovables, which constituted the principle of entry (draft art. 38 para. 1) ${ }^{34}$ Furthermore, an entry of a right evidenced in the land and mortgage register should be presumed to be reflecting the actual legal status of immovable property (presumption of the compliance of the entry with the actual legal status of immovable property). It was also enshrined that non-compliance of the land and mortgage register with the actual legal status of immovable property should not be prejudicial to any person who, by performing a juridical act, had acquired a proprietary right or a right resulting from a real burden, unless that person acted in bad faith (land and mortgage registers' public credibility warranty). ${ }^{35}$

The second reading of the draft of the Property Law of 1937 was concluded on 7 July 1939, less than two months before the outbreak of the Second World War. Editing work on the draft was continued in conspiracy conditions and the final version thereof was drawn up in $1941 .^{36}$

\subsection{Land and mortgage register law in the period of communism}

\subsubsection{Finalisation of the process of unification of land and mortgage register law in the 1940s}

As a result of the post-Yalta order being introduced, a communist administration fully reliant on Moscow was installed in the Polish territories, along with a murderous operation of liquidating the civilian and military structures of the Polish Underground State. At the same time, the legitimate Polish government-in-exile was denied in the international arena by the Soviet authorities. Gradually, the communists took over all the areas of the nation's life, by exercising terror and brutally suppressing any form of resistance. Repressive actions were undertaken not only against Poles involved in a further fight for independence, but also against potential opponents of the communist system. In the second half of 1940s and the early 1950 s, the totalitarian regime imposed by the communist party, which ruled the country on behalf of USSR, attained its full form. ${ }^{37}$ Pursuant to the Constitution

34 See J. Wasilkowski, op. cit., pp. 285-286; J. Górski, op. cit., p. 24. The principle of entry was one of contentious issues during the process of drafting the property law provisions. See further e.g. J. Kuropatwiński, Księgi wieczyste..., pp. 56-57; L. Górnicki, Prawo cywilne w pracach..., pp. 351-396.

35 See J. Górski, op. cit., p. 27.

36 L. Górnicki, Prawo cywilne w pracach..., pp. 317 ff.; J. Kuropatwiński, Księgi wieczyste..., p. 55.

37 See e.g. F. Musiał, "Stalinism in Poland", The Person and the Challenges 9, 2019, no. 2, pp. 9-23; W. Bernacki et al., Komunizm w Polsce. Zdrada, zbrodnia, zaktamanie, zniewolenie, Kraków 2005; D. Malec, op. cit., pp. 77-78. 
adopted by the communists in $1952,{ }^{38}$ the hitherto name of the Polish State, i.e. the Republic of Poland (Rzeczpospolita Polska), was replaced by a new one, the People's Republic of Poland (Polska Rzeczpospolita Ludowa). ${ }^{39}$

Under those circumstances, works on the unification of civil law restarted in 1945 , with the aim to not only overcome the existing differentiation of legal solutions, but also to impose reforms subordinated to the reconstruction of the social system. The Codification Commission, however, was not reactivated. ${ }^{40}$ The process of codification was coordinated by the Ministry of Justice. Drafts of legal acts were prepared by the Legal Commission at the Legislative Department of the Ministry of Justice, and then submitted to the State National Council (Krajowa Rada Narodowa), with no public discussion thereon being foreseen. ${ }^{41}$

As regards property law, notwithstanding the discontinuation of the interwar Codification Commission's activity, it was its draft of the Property Law in the second reading version that was taken as the basis of the future unified legislation. At the request of the Ministry of Justice, an explanatory memorandum to the draft was prepared. ${ }^{42}$ Moreover, some amendments, not yet of an ideological character, were implemented into the draft. ${ }^{43}$ Further works conducted by the abovementioned Legal Commission resulted in the introduction by the State National Council of three decrees of 11 October 1946, which entered into force on 1 January 1947: the Property Law Decree (hereinafter referred to as: PLD) ${ }^{44}$ the Land and Mortgage Registers Law Decree (hereinafter referred to as: LMRLD), ${ }^{45}$ and the Provisions Implementing Property Law and the Land and Mortgage Registers Law Decree. ${ }^{46}$ Matters governed by LMRLD included the organisation of land and mortgage registers as well as the proceedings, whereas provisions concerning rights evidenced in land and mortgage registers were contained in PLD

${ }^{38}$ Constitution of the People's Republic of Poland enacted by the Legislative Sejm on 22 July 1952 (Journal of Laws No. 33, Item 232, as amended).

39 See further e.g. D. Malec, op. cit., p. 76.

40 See further e.g. A. Lityński, Historia prawa Polski Ludowej, Warszawa 2013, pp. 190 ff.; S. Grodziski, op. cit., pp. 19 ff.; T. Maciejewski, op. cit., p. 390; W. Dajczak, op. cit., pp. 51-52.

${ }^{41}$ A. Lityński, op. cit., p. 191; S. Grodziski, op. cit., pp. 21-24; E.M. Guzik-Makaruk, P. Fiedorczyk, op. cit., pp. 26-27. On the process of subordination of the Polish civil law to the Soviet model, see further e.g. P. Fiedorczyk, "Polscy prawnicy emigracyjni o sowietyzacji prawa cywilnego", Studia nad Faszyzmem i Zbrodniami Hitlerowskimi 33, 2011, pp. 481-492; A.W. Rudzinski, "Sovietization of civil law in Poland", The American Slavic and East European Review 15, 1956, no. 2, pp. 216-246.

42 See S. Grzybowski, "Projekt prawa rzeczowego przygotowany przez Komisję Kodyfikacyjną w 1939 r.”, Kwartalnik Prawa Prywatnego 1993, no. 4, pp. 515-519; "Projekt prawa rzeczowego przyjęty w lipcu 1939 r. w drugim czytaniu przez podkomisję prawa rzeczowego", [in:] ibidem, pp. 520-567.

43 J. Kuropatwiński, Księgi wieczyste..., p. 58.

44 Journal of Laws No. 57, Item 319, as amended.

45 Journal of Laws No. 57, Item 320, as amended.

46 Journal of Laws No. 57, Item 321, as amended. 
(arts. 14-27). Rules laid down in both the above decrees were generally consistent with the relevant content of the Codification Commission's draft of the Property Law, the main difference being the abolition of the principle of entry. Pursuant to art. 43 PLD, ownership should be transferred by way of a contract between the owner and the acquiring party. Therefore, with respect to the transfer of ownership, the effect of registration was not constitutive, but declaratory. A constitutive entry in the land and mortgage register was required in cases specified by relevant provisions, such as, e.g., the creation of a mortgage. ${ }^{47}$

On 1 January 1947, the process of unifying the land and mortgage register system formally began in the whole country. In practice, however, the implementation of a single template of the new land and mortgage register encountered difficulties. ${ }^{48}$ As a result, for the next several decades, former types of registers had existed alongside the newly set up land and mortgage registers, based on the unified template. ${ }^{49}$ Nevertheless, it is considered a significant achievement of the unification of land and mortgage register law that it has resulted in developing an original model of a perpetual book, constituting a Polish variant of the Central European land register, which, having proven its practical usefulness, is followed until the present day. ${ }^{50}$

\subsubsection{Dispute as to the role of land and mortgage registers in the socialist system}

In the early 1950s, a controversy arose regarding the need to maintain the institution of land and mortgage register under the conditions of the socialist system. ${ }^{51}$ The position of land and mortgage registers as the organisational and legal basis of real estate transactions and mortgage lending was undermined on the grounds of deeming individual ownership of land temporary and diminishing the relevance of mortgage credit. Widely represented in the legal scholarship, such a stance was in line with general political criticism of property law regulations, considered to be

47 See A. Lityński, op. cit., pp. 193-195.

48 See e.g. S. Breyer, "Technika prowadzenia ksiąg wieczystych”, Przegląd Notarialny 1947, no. 4 , pp. 325-326.

49 J. Ignatowicz, J. Wasilkowski, [in:] System prawa cywilnego, vol. 2. Prawo własności i inne prawa rzeczowe, ed. J. Ignatowicz, Wrocław 1977, p. 895.

50 J. Kuropatwiński, Księgi wieczyste..., p. 59.

51 See e.g. S. Breyer, "Księgi wieczyste de lege ferenda", Nowe Prawo 1953, no. 2, pp. 27 ff.; idem, "Problem ksiąg wieczystych", Nowe Prawo 1964, no. 1, pp. 238 ff.; J. Wasilkowski, "Zagadnienie hipoteki i ksiąg wieczystych w przyszłym prawie cywilnym”, Państwo i Prawo 1955, no. 5, pp. 587, 608-609; J. Marowski, "Niektóre zagadnienia kodyfikacji prawa rzeczowego", Nowe Prawo 1952, no. 8-9, p. 33. Further on these issues, see A. Lityński, op. cit., pp. 213-214; E. Gniewek, "Miejsce ksiąg wieczystych w systemie prawa cywilnego", [in:] Czterdzieści lat kodeksu cywilnego. Materiały z Ogólnopolskiego Zjazdu Cywilistów w Rzeszowie (8-10 października 2004 r.), ed. M. Sawczuk, Kraków 2006, pp. 128 ff.; W.T. Buczek-Markowska, "Rola i zadania ksiąg wieczystych na tle przekształceń gospodarczych”, Rejent 1996, no. 7-8, pp. 131 ff.; B. Barłowski, E. Janeczko, Księgi wieczyste — rejestr nieruchomości, Warszawa 1988, pp. 6-7. 
based on inappropriate foundations inherent to the capitalist system. The above approach found its expression particularly during the works on a civil code, which were conducted by the Codification Commission established in $1956^{52}$ and resulted in the enactment of the Civil Code of 23 April $1964^{53}$ (Kodeks cywilny - hereinafter referred do as: $\mathrm{CC}$ ). At that time, it was even suggested that the institution of land and mortgage register should be abolished as it was incompatible with the basic premises underpinning the socialist economy and therefore expendable. ${ }^{54}$

Ultimately, it was decided not to eliminate land and mortgage registers from the legal system, but to leave the provisions thereon outside $\mathrm{CC}$. The rationale for the above solution was that the then existing transition conditions, before the formation of the socialist system in Poland was completed, were still characterised by a variety of property law relations, with a significant share of individual ownership of land in rural areas (according to the assumptions of the People's Republic of Poland's rural policy, individual farms were destined to eventually be subject to socialisation). Based on those arguments, the Codification Commission managed to resist the ideological pressure from the supporters of radical legislative actions. ${ }^{55}$ Upon the entrance into force of CC on 1 January 1965, PLD was repealed, with the exception of arts. 14-27, relating to land and mortgage registers. ${ }^{56}$ LMRLD remained in force as well. At the same time, it was envisaged that the system of land and mortgage registers would be subject to a thorough reform, and a draft of a new act would be prepared in which all the matters regarding land and mortgage registers as well as mortgage would be jointly regulated. As intended, the future provisions were supposed to be patterned after the Mortgage Act of 1818. In 1966, a draft of land and mortgage register and mortgage law was elaborated by a commission appointed by the Minister of Justice. ${ }^{57}$ Because of

52 The Codification Commission acted within the Ministry of Justice and did not enjoy autonomy. Nonetheless, in its activity, it implicitly referred to the output of the Codification Commission of the Second Republic of Poland. The codification works carried out between 1956 and 1964 were preceded by endeavours undertaken by a commission for the preparation of a unified civil code, established directly after the war, in 1947. Draft laws elaborated in the next years, however, were not subject to legislative process. See further e.g. M. Mazuryk, I. Sadowski, op. cit., pp. 13-15; A. Lityński, op. cit., pp. 204-205, 222 ff.; idem, "Nowe ustawodawstwo w nowym ustroju. O prawie karnym i cywilnym w pierwszym dwudziestoleciu Polski Ludowej”, Miscellanea Historico-Iuridica 4, 2006, pp. 135-138; A. Moszyńska, "Prace nad kodyfikacją majątkowego prawa cywilnego w latach 1950-52", Miscellanea Historico-Iuridica 14, 2015, no. 2, pp. 165-180; eadem, "Work on the Polish Civil Code in Stalinist period (1948-1956)", Právněhistorické Studie 49, 2020, no. 2, pp. 30-38.

53 Consolidated text: Journal of Laws of 2020 Item 1740, as amended.

54 A. Stelmachowski, "W kwestii przyszłości ksiąg wieczystych", Nowe Prawo 1964, no. 3 , pp. $229 \mathrm{ff}$.

55 E. Gniewek, op. cit., p. 129.

56 See art. III point 3 of the Act of 23 April 1964 - Provisions Implementing the Civil Code (Journal of Laws No. 16, Item 94, as amended).

57 See S. Rudnicki, "Nowy projekt prawa o księgach wieczystych i hipotece", Nowe Prawo 1968 , no. 12, pp. $1748-1749$. 
the ongoing dispute over the role of land and mortgage registers in a communist country, however, works on that draft had not been continued, and a situation of temporariness in this regard had persisted for an extended period of time. ${ }^{58}$

Moreover, a departure from the long-held organisational premises of the system of land and mortgage registers was demonstrated in 1964 by conferring ${ }^{59}$ the tasks connected with keeping them, previously exercised by the courts, on the state notarial offices (państwowe biura notarialne), which had the status of state bodies operating under the supervision of the Ministry of Justice. ${ }^{60}$

\subsubsection{The impact of the evolution of rural policy on the enactment of the Land and Mortgage Registers and Mortgage Act in 1982}

The marginalisation of the institution of land and mortgage register in the People's Republic of Poland period was largely due to rural policy pursued by the communist authorities, whose primary objective was to socialise the farming sector, especially by transforming individual ownership of land into state ownership (state farms - państwowe gospodarstwa rolne). ${ }^{61}$ In the course of time, however, the attitude towards the position of individual farms in the People's Republic of Poland's socio-economic system had changed, as reflected in legislative amendments and doctrinal views.

What had substantially contributed to preventing full nationalisation of farms from being implemented was strong resistance from the Polish farmers who from the beginning had consistently opposed compulsory farmland collectivisation. Moreover, already since the mid-1970s, they had fought for their union rights. In 1980, alongside with the creation of the Solidarity anti-communist movement following the strike in the Gdańsk Shipyard, a union of Polish farmers called Rural Solidarity was established. Given the communist government's refusal to legitimise the union, farmers' protests began in the late 1980 and early 1981, ultimately leading to the signing of the so-called Ustrzyki-Rzeszów Agreement of 18 and 20 February 1981, which guaranteed individual ownership of land, although the government did not yet agree to the registration of the farmers' Solidarity. It should be underlined that the emergence of the rural anti-communist movement would not have been possible without the support provided by the Polish Church, and

58 J. Kuropatwiński, Księgi wieczyste..., pp. 60-61; J. Skąpski, op. cit., p. 114.

59 Act of 16 November 1964 on Entrusting the State Notarial Offices with the Keeping of Land and Mortgage Registers (Journal of Laws No. 41, Item 248).

60 See further e.g. J. Pisuliński, op. cit., pp. 34-34; D. Malec, op. cit., p. 79.

61 See further e.g. T. Maciejewski, op. cit., p. 396; M. Niedośpiał, "Wprowadzenie do części I", [in:] M. Niedośpiał, B. Wacławik, Prawo własności. Aspekty prawne-etyczne (moralne) - społeczne - filozoficzne - ekonomiczno-finansowe, Warszawa 2013, pp. 26-31; D. Malec, op. cit., pp. 78-79; T. Mróz, "The role of property law in creating the basis of the market economy after 1989 (regarding the historical context)", Optimum. Economic Studies 2019, no. 4, pp. 135 ff.; L.B. Koziebrodzki, "Polish agrarian law", [in:] Polish Civil Law, ed. D. Lasok, vol. 1, Leiden 1973, pp. 117 ff. 
personally by Blessed Cardinal Stefan Wyszyński, Primate of Poland, who had been deeply involved in defending the inalienable rights of the people, including the right to individual possession and disposition of farmland, as well as the development of favourable conditions for individual farms. ${ }^{62}$ Thanks to the interventions of Primate Wyszyński, the conflict concerning the acknowledgment of Rural Solidarity was finally resolved in the so-called Agreement of Bydgoszcz of 17 April 1981, and after passing a special law on trade unions of individual farmers by the Sejm, the registration of the union took place on 12 May $1981 .{ }^{63}$

The turn in state policy towards the farming sector at the beginning of the 1980s was accompanied by changes at the legislative level that found their expression in a new wording of art. $131 \mathrm{CC}$. In its original version, the above provision contained a declaration that 'care should be provided by the People's Republic of Poland for individual farms of working farmers.' As amended in 1982, art. 131 $\mathrm{CC}$ read that the People's Republic of Poland 'guaranteed ownership and full protection of individual farms, which constituted a permanent and equal element of the socio-economic system. ${ }^{64}$ What is more, by virtue of the Act amending the Constitution of the People's Republic of Poland of 20 July 1983, ${ }^{65}$ the permanence of individual farms was guaranteed constitutionally (art. 15 point 3 of the Constitution of the People's Republic of Poland). ${ }^{66}$

Against the changing political background, land and mortgage registers gradually had started to regain importance as well, which was evidenced by the opinions expressed in the legal scholarship as far back as the 1970s. It was recognised that land and mortgage registers performed a significant function in ensuring certainty and transparency of property law relations, and proved to be useful in respect of individual ownership of farms. ${ }^{67}$

The above described conditions, in particular the stabilisation and further acceptance of individual farms in the social and legal system, appeared to be favourable for discarding the notion of land and mortgage register as a merely temporary

${ }^{62}$ Cardinal Stefan Wyszyński was beatified on 12 September 2021.

63 Subsequently, Rural Solidarity was delegalised upon the introduction of martial law on 13 December 1981, and was re-registered only on 20 April 1989. See further e.g. K. Maniewska, Narodziny i działalność rolniczej "Solidarności" 1981-1989, Bydgoszcz-Gdańsk-Warszawa 2020; A.W. Kaczorowski, T. Kozłowski, J. Olaszek, "Solidarność” Rolników 1980-1989, Warszawa 2010; A.W. Kaczorowski, The Primate of Poland and Farmers' 'Solidarity', https://ipn.gov.pl/ en/digital-resources/articles/8119, The-Primate-of-Poland-and-Farmers039-039Solidarity039.html (accessed: 27.09.2021).

64 See e.g. E. Gniewek, op. cit., pp. 129-130; R. Budzinowski, "Indywidualne gospodarstwa rolne w ustroju społeczno-gospodarczym PRL (Rozważania na tle art. 131 k.c.)”, Ruch Prawniczy, Ekonomiczny i Socjologiczny 1983, no. 2, pp. 1-19.

65 Journal of Laws No. 39, Item 175.

66 See e.g. J. Skąpski, op. cit., p. 115; M. Niedośpiał, op. cit., p. 28.

67 See e.g. S. Breyer, Przeniesienie własności nieruchomości, Warszawa 1975, p. 215; S. Grzybowski, Prawo cywilne. Zarys prawa rzeczowego, Warszawa 1976, p. 229; Z.K. Nowakowski, Prawo rzeczowe. Zarys wyktadu, Warszawa 1980, p. 259. 
institution, and eventually allowed LMRMA to be enacted in 1982. In this way, the relevance of land and mortgage registers was reaffirmed, even though they were regulated by an ordinary act, instead of by CC. By virtue of LMRMA, which entered into force on 1 January 1983, the until-then-in-force LMRLD and arts. 14-27 PLD were repealed, with the organisational, procedural and substantive rules contained therein, respectively, being basically preserved under the new legislation. ${ }^{68}$

\subsection{Development of Land and Mortgage Registers from the 1990s to present}

Anti-communist protests undertaken through the decades of the People's Republic of Poland period, together with increasing crisis of the centrally planned socialist economy, entailed gradual erosion of the communist regime, the result being the systemic transformation initiated in 1989, and the formation of the Third Republic of Poland as a democratic state based on the rule of law. ${ }^{69}$ Social and political transition in Poland has brought about a shift in the approach to property law relations. Private ownership is now recognised as one of the principal elements on which a social market economy, constituting the foundation of the economic system of the Republic of Poland, is based, as enshrined in art. 20 of the Polish Constitution of 2 April $1997 .^{70}$ Significant changes have also been successively introduced since the early 1990s as regards provisions governing land and mortgage registers.

As of 22 March 1991, by virtue of the Act of 14 February 1991 - Provisions Implementing the Notarial Law Act and amending the Code of Civil Procedure as well as the Land and Mortgage Registers and Mortgage Act, ${ }^{71}$ the state notarial offices were abolished, and the keeping of land and mortgage registers was again entrusted to the judiciary (district courts - sady rejonowe). Today, as laid down in art. 23 LMRMA, the competence to keep land and mortgage registers is vested in district courts in which special land and mortgage register divisions are established. Relevant court activities regarding the keeping of land and mortgage registers may be performed by court referees (referendarze sadowi). Thereby, the previously well-established tradition in Polish law was continued. ${ }^{72}$ Worthy of note is that in subsequent years, calls for reorganisation of land and mortgage registers were put forward. The proposed reforms were intended to streamline the

68 E. Gniewek, op. cit., p. 130; J. Pisuliński, op. cit., p. 34. Cf. A. Szpunar, "Nowa ustawa o księgach wieczystych i hipotece", Państwo i Prawo 1983, no. 5, pp. 3 ff.

69 See e.g. D. Malec, op. cit., pp. 82-83.

70 Journal of Laws No. 78, Item 483, as amended. See further e.g. E. Gniewek, op. cit., pp. 130 131; A. Lityński, Historia prawa..., p. 230.

71 Journal of Laws No. 22, Item 92.

72 See e.g. J. Sadomski, K. Zaradkiewicz, Wybrane zagadnienia reformy wymiaru sprawiedliwości - głos $w$ dyskusji, raport Instytutu Wymiaru Sprawiedliwości no. 51, Warszawa 2005, p. 19; B. Zdziennicki, op. cit., pp. 8, 14-15. 
registration procedure by privatising land and mortgage registers, ${ }^{73}$ but ultimately, not being approved by the Ministry of Justice, they were not implemented. ${ }^{74}$

Further significant amendments to LMRMA included, i.a., the repeal in $2001^{75}$ of the provisions on land and mortgage register proceedings, which from then on are governed by arts. $626^{1}-626^{13}$ of the Code of Civil Procedure of 17 November $1964^{76}$ (Kodeks postepowania cywilnego - hereinafter referred to as: CCP). Nevertheless, the delimitation of issues covered by Section I LMRMA, which deals with land and mortgage registers, and the CCP, respectively, is not strict. ${ }^{77}$

The last decades have also been marked by consistent efforts undertaken to increase the efficiency of the system of land and mortgage registers through extensive application of new technologies. Already in the early 1990s, the process of computerisation of land and mortgage registers started, and subsequently was followed by the informatisation (digitisation) phase. ${ }^{78}$ The statutory basis for informatisation of land and mortgage registers was art. $25^{1}$ para. 1 LMRMA, added by way of the amendment of 2001 cited above. Based on the so-called Migration Act of 14 July $2003,{ }^{79}$ the transfer of the content of 'physical' (paper) land and mortgage registers to the electronic ones commenced. Upon the completion in 2014 of the process of migration, land and mortgage registers are now set up and kept in the information technology data transmission system (art. $25^{1}$ para. 1 LMRMA in the present wording). For the purpose of keeping electronic land and mortgage registers, a central land and mortgage registers' database (centralna baza danych ksiag wieczystych) has been established. It constitutes the national collection of land and mortgage registers kept in the information technology data transmission system, and is maintained by the Minister of Justice (art. $36^{3}$ para. 1 LMRMA). ${ }^{80}$

73 See further e.g. L. Zabielski, "Prowadzenie ksiąg wieczystych i innych rejestrów publicznych. Ocena i kierunki zmian", Nowy Przeglad Notarialny 2001, no. 7-8, pp. 16 ff.; Z. Bystrzycka, "Księgi wieczyste - w domu u właściciela", Rejent 2001, no. 6, pp. $172 \mathrm{ff}$.

74 Further on this issue, see e.g. E. Gniewek, op. cit., pp. 135-136; J. Pisuliński, op. cit., pp. $35-36$.

75 Act of 11 May 2001 amending the Land and Mortgage Registers and Mortgage Act, the Code of Civil Procedure, the Act on Court Costs in Civil Matters and the Notarial Law Act (Journal of Laws No. 63, Item 635).

76 Consolidated text: Journal of Laws of 2020 Item 1575, as amended.

77 See further e.g. S. Rudnicki, "Zmiana ustawy o księgach wieczystych i hipotece”, Rejent 2001, no. 10, pp. 31-39; E. Gniewek, op. cit., pp. 132-134; J. Pisuliński, op. cit., p. 34.

78 See further e.g. J. Gołaczyński, "Informatyzacja ksiąg wieczystych. Uwagi ogólne”, [in:] Informatyzacja ksiagg wieczystych i postepowania wieczystoksięgowego, ed. J. Gołaczyński, Warszawa 2020, pp. 3-39; A. Gryszczyńska, Nowa Księga Wieczysta. Informatyzacja rejestru publicznego, Warszawa 2011; A. Stefańska, Elektroniczna księga wieczysta, Warszawa 2011; D. Bogucki, "Projekt Nowa Księga Wieczysta a reforma ksiąg wieczystych", Rejent 1998, no. 6, pp. 13-22.

79 Act of 14 February 2003 on Transferring the Content of Land and Mortgage Register into the Structure of Land and Mortgage Register Kept in the Information Technology System (Journal of Laws No. 42, Item 363, as amended).

80 See e.g. J. Kuropatwiński, Księgi wieczyste..., pp. 61 ff.; A. Gryszczyńska, "Migracja ksiąg wieczystych", [in:] Elektroniczne aspekty wymiaru sprawiedliwości, eds. G. Tylec, J. Misztal-Konecka, Bydgoszcz-Lublin 2009, pp. 43-54. 
As hitherto, in general, a separate land and mortgage register shall be kept for each single immovable property (art. 24 para. 1 sentence 1 LMRMA). The informatisation has not basically modified the structure of the land and mortgage register. It consists of four sections, of which:

1. the first contains the designation of immovable property and the entries of the rights concerning its ownership;

2. the second contains the entries concerning the ownership and perpetual usufruct;

3. the third is intended for entries concerning limited proprietary rights, except for mortgages, for entries concerning restrictions on the disposals of the immovable property or of its perpetual usufruct, as well as for entries concerning other rights or claims, except for claims concerning mortgages;

4. the fourth is intended for entries concerning mortgages (art. 25 para. 1 LMRMA). ${ }^{81}$

The basis for the designation of land in the land and mortgage register shall be the real estate cadastre data (art. 26 para. 1 LMRMA). In the existing Polish legal framework, it is the land and buildings register (ewidencja gruntów i budynków) that is equated with the real estate cadastre. Currently, the Integrated Land Information System (Zintegrowany System Informacji o Nieruchomościach) is under implementation, with the aim to ensure interoperability of land and mortgage registers and the cadastre. ${ }^{82}$

The information from the central land and mortgage registers' database, in both electronic and paper formats, is provided by the Central Information Office of the Land and Mortgage Registers (Centralna Informacja Ksiag Wieczystych), having its agencies at the district courts divisions which keep land and mortgage registers (art. $36^{4}$ para. 1 LMRMA). The introduction of new methods of access to electronic land and mortgage registers, including common online access (art. $36^{4}$ paras. 3-5 LMRMA), has contributed to enhancing their information function as well as extending the guarantees of formal and substantive publicity, under the present state of the law finding its expression in art. 2 LMRMA. $^{83}$

81 See e.g. B. Prus, "Organizacja struktury ksiąg wieczystych w Polsce”, Infrastruktura i Ekologia Terenów Wiejskich 2011, no. 3, pp. 183 ff.; T. Sokołowski, "Property law”, [in:] Foundations of Law..., p. 187.

82 See e.g. K. Góźdź, “Interoperacyjność zbiorów informacji o nieruchomościach w Polsce”, [in:] Rejestry publiczne. Jawność i interoperacyjność, ed. A. Gryszczyńska, Warszawa 2016, pp. 459 ff.; J. Grzesiak, "Zintegrowany system informacji o nieruchomościach", Nieruchomości 2015, no. 5, p. 47.

83 See e.g. A. Gryszczyńska, "Jawność formalna ksiąg wieczystych w Polsce”, [in:] Rejestry publiczne. Jawność..., pp. 261 ff.; J. Bydłosz, "Wybrane zagadnienia związane z dostępem do ksiąg wieczystych drogą elektroniczną”, Świat Nieruchomości 2011, no. 77, pp. 14 ff.; M. Leśniak, "Powszechny dostęp do przeglądania księgi wieczystej prowadzonej w systemie informatycznym (nowej księgi wieczystej)", Prawo Mediów Elektronicznych 2010, no. 3, pp. 21 ff.; A. RogackaŁukasik, "Jawność ksiąg wieczystych w świetle nowelizacji przepisów w 2013 roku", Przegląd Ustawodawstwa Gospodarczego 2014, no. 11, pp. 15 ff.; P. Siciński, "Nowe ujęcie jawności formalnej ksiąg wieczystych", part 1. Nieruchomości 2014, no. 8, pp. 4 ff.; part 2: Nieruchomości 2014, 
Considerable progress can also be observed as regards implementing innovative technological solutions in land and mortgage register proceedings. The first phase of informatisation thereof started with the entrance into force of the Act of 15 January 2015 amending the Code of Civil Procedure and Several Other Acts, ${ }^{84}$ by virtue of which, as of 1 July 2016 notaries, court executive officers and heads of tax offices are obliged to submit applications for entry in the land and mortgage register via the information technology data transmission system, with the use of official forms and qualified electronic signatures. ${ }^{85}$

What needs to be emphasised is that the abovementioned modernisation initiatives carried out in the field of land registration have reached an advanced stage. Therefore, Poland can be considered one of the leading European jurisdictions in regard of improving availability of land information and increasing the effectiveness of the registration procedure. ${ }^{86}$

In addition to the aforementioned remarks, it is worth indicating that under the present state of the law, unchanged remain substantive principles underlying the functioning of land and mortgage registers. As a rule, registration in the land and mortgage register has merely declaratory effect. However, by virtue of art. 34 para. 1 LMRMA, the owner is obliged to immediately submit a relevant application for having his or her right evidenced in the land and mortgage register. A constitutive entry in the land and mortgage register is required only in cases provided for by law, including, i.a., the creation and transfer of perpetual usufruct, the creation of separate premises as well as the creation and transfer of mortgage. Among other principles still enshrined by LMRMA are the presumption of the compliance of the entry with the actual legal status of immovable property as well as land and mortgage registers' public credibility warranty. ${ }^{87}$

no. 9, pp. 17 ff.; M. Kaczorowska, "Realizacja zasady jawności ksiąg wieczystych w prawie polskim w dobie informatyzacji. Zarys problematyki”, [in:] Informatyzacja ksiag wieczystych..., pp. 54 ff.

84 Journal of Laws Item 218 , as amended.

85 See e.g. J. Gołaczyński, op. cit., pp. 36-38; P. Biernacki, G. Mikołajczuk, Wniosek o wpis w księdze wieczystej po nowelizacji. Komentarz praktyczny. Opłaty sądowe, wzór wniosku o wpis, Warszawa 2017; A. Maziarz, "Wszczęcie postępowania wieczystoksięgowego drogą elektroniczną", [in:] Elektronizacja postępowania wieczystoksięgowego. Komentarz praktyczny. Akty wykonawcze, ed. A. Marciniak, Warszawa 2016, pp. $67 \mathrm{ff}$.

${ }^{86}$ See further e.g. P. Blajer, Rejestry nieruchomości..., pp. 838 ff.; M. Kaczorowska, "Postępy informatyzacji rejestrów nieruchomości w krajach Unii Europejskiej. Analiza prawnoporównawcza", [in:] Informatyzacja ksiag wieczystych..., pp. 149-391; eadem, "Informatisation of land registers in Poland and other Member States of the European Union: A comparative overview", Law and Forensic Science 17, 2019, no. 1, pp. 30-48.

${ }^{87}$ See e.g. M. Deneka, op. cit., pp. 78 ff.; T. Sokołowski, op. cit., p. 188. 


\section{Concluding remarks}

The difficulties involved in shaping land and mortgage register law from the revival of the independent Poland in 1918 and substantial interwar efforts invested in the unification and codification process, through the time of oppression by the communist system, until the period of democratic transformation at the turn of 1980s and 1990s, - can be an example that illustrates how heavily the course of the 20th century history weighed on the development of modern Polish legislation. At the same time, the communist authorities' failure to erase core institutions underlying the operation of society, such as land and mortgage registers (as well as individual ownership of land and mortgage), from the legal system evidences the strength of the Polish nation that had tenaciously opposed the post-war totalitarian regime. Despite the communist ideological pressure, land and mortgage registers related legal solutions elaborated by the interwar Codification Commission have not been squandered, and, after some modifications, are up to the present the foundation for real estate conveyancing under the LMRMA of 1982. With this in mind, it may be stated that, in a symbolic sense, land and mortgage registers have effectively proven to be resistant to destruction, and thus 'perpetual' indeed.

In recent years, much progress has been achieved as regards modernisation of the system of land and mortgage registers with the view to ensuring more effective performance of their functions, which has been stimulated by dynamic technological advancements. The contemporary development tendencies in the field of land registration are a clear manifestation of the acknowledgement of the essential relevance thereof in the real estate transactions domain. Furthermore, in connection with the recent initiative of recodification of civil law, calls are being put forward for transferring the land and mortgage register law provisions from LMRMA to the CC now in force, or a new code. ${ }^{88}$ As pointed out in the literature, the act of 1982 has already served its purpose by expressing at the legislative level the acceptance for the continuing operation of land and mortgage registers, contrary to the approach followed in the communist period, assuming their temporary character. ${ }^{89}$ Such an amendment would therefore actually underscore the rightful position of land and mortgage registers in the Polish legal system.

88 See e.g. Z. Radwański, “Zielona Księga. Optymalna wizja Kodeksu Cywilnego w Rzeczypospolitej Polskiej”, Ruch Prawniczy, Ekonomiczny i Socjologiczny 2007, no. 1, pp. 9 ff.; E. Gniewek, op. cit., pp. 130-131, 136; K. Zaradkiewicz, "Księga wieczysta i inne publiczne rejestry dóbr prawnych w pracach Komisji Kodyfikacyjnej Prawa Cywilnego", Rejent 2015, no. 5, pp. 201-223.

89 E. Gniewek, op. cit., p. 131. 


\section{Bibliography}

Barłowski B., Janeczko E., Księgi wieczyste - rejestr nieruchomości, Warszawa 1988.

Bernacki W. et al., Komunizm w Polsce. Zdrada, zbrodnia, zakłamanie, zniewolenie, Kraków 2005.

Biernacki P., Mikołajczuk G., Wniosek o wpis w księdze wieczystej po nowelizacji. Komentarz praktyczny. Opłaty sądowe, wzór wniosku o wpis, Warszawa 2017.

Blajer P., Rejestry nieruchomości. Studium prawnoporównawcze, Warszawa 2018.

Blajer P., "Z historii ksiąg gruntowych (Grundbücher)", Studia Prawnicze. Rozprawy i Materiaty 2015, no. 2.

Bogucki D., "Projekt Nowa Księga Wieczysta a reforma ksiąg wieczystych", Rejent 1998, no. 6.

Breyer S., "Księgi wieczyste de lege ferenda", Nowe Prawo 1953, no. 2.

Breyer S., "Problem ksiąg wieczystych", Nowe Prawo 1964, no. 1.

Breyer S., Przeniesienie wlasności nieruchomości, Warszawa 1975.

Breyer S., "Technika prowadzenia ksiąg wieczystych”, Przegląd Notarialny 1947, no. 4.

Buczek-Markowska W.T., "Rola i zadania ksiąg wieczystych na tle przekształceń gospodarczych", Rejent 1996, no. 7-8.

Budzinowski R., "Indywidualne gospodarstwa rolne w ustroju społeczno-gospodarczym PRL (Rozważania na tle art. 131 k.c.)", Ruch Prawniczy, Ekonomiczny i Socjologiczny 1983, no. 2.

Bydłosz J., "Wybrane zagadnienia związane z dostępem do ksiąg wieczystych drogą elektroniczną", Świat Nieruchomości 2011, no. 77.

Bystrzycka Z., "Księgi wieczyste - w domu u właściciela", Rejent 2001, no. 6.

Cámara Lapuente S., "Registration of interests as a formality of contracts: Comparative remarks on land registers within the frame of European private law", European Review of Private Law 2005, no. 6 .

Chwalba A., "Państwo, społeczeństwo, naród", [in:] Encyklopedia historyczna świata, vol. 14. Polska, ed. A. Chwalba, Kraków 2003.

D'Abernon E.V., The Eighteenth Decisive Battle of the World: Warsaw, 1920, London 1931.

Dajczak W., "Historical development of private law in Poland", [in:] Foundations of Law: The Polish Perspective, eds. W. Dajczak, T. Nieborak, P. Wiliński, Warszawa 2021.

Dalkowska M.A., "Geneza oraz kształt prawa hipotecznego na ziemiach polskich w XIX w.", Przeglad Ustawodawstwa Gospodarczego 2019, no. 3.

Deneka M., Księgi wieczyste. Zasady materialnoprawne, Warszawa 2012.

Domański L., "O istocie i znaczeniu Ustawy hipotecznej roku 1818-go", Gazeta Sądowa Warszawska 1918 , no. 43-45.

Fiedorczyk P., "Polscy prawnicy emigracyjni o sowietyzacji prawa cywilnego", Studia nad Faszyzmem i Zbrodniami Hitlerowskimi 33, 2011.

Gałędek M., "The beginning of the debate on the codification of Polish law after the World War I: The issue of the Codification Commission autonomy in the light of political declarations", Studia Iuridica 80, 2019.

Glass J., Zarys prawa hipotecznego w b. Królestwie Polskiem, Warszawa-Kraków 1921.

Gniewek E., "Miejsce ksiąg wieczystych w systemie prawa cywilnego", [in:] Czterdzieści lat kodeksu cywilnego. Materiały z Ogólnopolskiego Zjazdu Cywilistów w Rzeszowie (8-10 października 2004 r.), ed. M. Sawczuk, Kraków 2006.

Golab S., "The codification of Polish law", Journal of Comparative Legislation and International Law 6, 1924, no. 1.

Gołaczyński J., "Informatyzacja ksiąg wieczystych. Uwagi ogólne”, [in:] Informatyzacja ksiag wieczystych i postępowania wieczystoksięgowego, ed. J. Gołaczyński, Warszawa 2020.

Górnicki L., "Komisja Kodyfikacyjna II RP: pozycja ustrojowa, struktura organizacyjna, podejmowanie decyzji”, Prawo 328, 2019. 
Górnicki L., "Prawa rzeczowe”, [in:] Synteza prawa polskiego 1918-1939, eds. T. Guz, M.R. Pałubska, J. Głuchowski, Warszawa 2013.

Górnicki L., Prawo cywilne w pracach Komisji Kodyfikacyjnej Rzeczypospolitej Polskiej w latach 1919-1939, Wrocław 2000.

Górski J., "O projekcie prawa rzeczowego", Ruch Prawniczy, Ekonomiczny i Socjologiczny 1938, no. 1.

Góźdź K., "Interoperacyjność zbiorów informacji o nieruchomościach w Polsce", [in:] Rejestry publiczne. Jawność i interoperacyjność, ed. A. Gryszczyńska, Warszawa 2016.

Grodziski S., "Prace nad kodyfikacją i unifikacją polskiego prawa prywatnego (1919-1947)", Kwartalnik Prawa Prywatnego 1992, no. 1-4.

Gryszczyńska A., "Jawność formalna ksiąg wieczystych w Polsce”, [in:] Rejestry publiczne. Jawność i interoperacyjność, ed. A. Gryszczyńska, Warszawa 2016.

Gryszczyńska A., "Migracja ksiąg wieczystych", [in:] Elektroniczne aspekty wymiaru sprawiedliwości, eds. G. Tylec, J. Misztal-Konecka, Bydgoszcz-Lublin 2009.

Gryszczyńska A., Nowa Księga Wieczysta. Informatyzacja rejestru publicznego, Warszawa 2011.

Grzesiak J., "Zintegrowany system informacji o nieruchomościach”, Nieruchomości 2015, no. 5.

Grzybowski S., Prawo cywilne. Zarys prawa rzeczowego, Warszawa 1976.

Grzybowski S., "Projekt prawa rzeczowego przygotowany przez Komisję Kodyfikacyjną w 1939 r.”, Kwartalnik Prawa Prywatnego 1993, no. 4.

Guzik-Makaruk E.M., Fiedorczyk P., "The achievements of the Codification Commission of the Second Republic of Poland - a century after regaining the independence", Internal Security 2018, special issue.

Ignatowicz J., Stefaniuk K., Prawo rzeczowe, Warszawa 2012.

Ignatowicz J., Wasilkowski J., [in:] System prawa cywilnego, vol. 2. Prawo własności i inne prawa rzeczowe, ed. J. Ignatowicz, Wrocław 1977.

Kaczorowska M., "Informatisation of land registers in Poland and other Member States of the European Union: A comparative overview", Law and Forensic Science 17, 2019, no. 1.

Kaczorowska M., "Postępy informatyzacji rejestrów nieruchomości w krajach Unii Europejskiej. Analiza prawnoporównawcza", [in:] Informatyzacja ksiąg wieczystych i postępowania wieczystoksięgowego, ed. J. Gołaczyński, Warszawa 2020.

Kaczorowska M., "Realizacja zasady jawności ksiąg wieczystych w prawie polskim w dobie informatyzacji. Zarys problematyki”, [in:] Informatyzacja ksiag wieczystych i postepowania wieczystoksięgowego, ed. J. Gołaczyński, Warszawa 2020.

Kaczorowski A.W., The Primate of Poland and Farmers' "Solidarity”, https://ipn.gov.pl/en/digital-resources/articles/8119, The-Primate-of-Poland-and-Farmers039-039Solidarity039.html (accessed: 27.09.2021).

Kaczorowski A.W., Kozłowski T., Olaszek J., ,, Solidarnośc’” Rolników 1980-1989, Warszawa 2010.

Kola J., "Działalność Komisji Kodyfikacyjnej RP w obszarze prawa zobowiązań. Refleksje z okazji 80. rocznicy kodeksu zobowiązań", Palestra 2013, no. 9-10.

Korkuć M., The Fighting Republic of Poland 1939-1945, Warszawa 2019.

Koziebrodzki L.B., "Polish agrarian law", [in:] Polish Civil Law, ed. D. Lasok, vol. 1, Leiden 1973.

Kuropatwiński J., [in:] Ustawa o księgach wieczystych i hipotece. Komentarz, eds. M. Habdas, M. Fras, Warszawa 2021.

Kuropatwiński J., Księgi wieczyste. Komentarz do art. 1-58 u.k.w.h. oraz art. $626^{1}-626^{13}$ k.p.c., vol. 1, Komentarz do art. 1-10 ustawy o księgach wieczystych i hipotece, Bydgoszcz 2013.

Leśniak M., "Powszechny dostęp do przeglądania księgi wieczystej prowadzonej w systemie informatycznym (nowej księgi wieczystej)”, Prawo Mediów Elektronicznych 2010, no. 3.

Lityński A., Historia prawa Polski Ludowej, Warszawa 2013.

Lityński A., "Nowe ustawodawstwo w nowym ustroju. O prawie karnym i cywilnym w pierwszym dwudziestoleciu Polski Ludowej”, Miscellanea Historico-Iuridica 4, 2006. 
Maciejewski T., Historia ustroju i prawa sadowego Polski, Warszawa 2017.

Malec D., "Ustrój i prawo XX w.", [in:] Encyklopedia historyczna świata, vol. 14. Polska, ed. A. Chwalba, Kraków 2003.

Maniewska K., Narodziny i działalność rolniczej „,Solidarności” 1981-1989, Bydgoszcz-Gdańsk-Warszawa 2020.

Markiewicz J., "Kształtowanie się polskiego systemu prawa sądowego i jego twórcy w okresie międzywojennym 1919-1939 (Wybrane zagadnienia)", Teka Komisji Prawniczej — Oddziat Lubelski PAN 3, 2010.

Marowski J., "Niektóre zagadnienia kodyfikacji prawa rzeczowego", Nowe Prawo 1952, no. 8-9.

Maziarz A., "Wszczęcie postępowania wieczystoksięgowego drogą elektroniczną", [in:] Elektronizacja postępowania wieczystoksięgowego. Komentarz praktyczny. Akty wykonawcze, ed. A. Marciniak, Warszawa 2016.

Mazuryk M., Sadowski I., “Organizacja i funkcjonowanie komisji kodyfikacyjnych prawa cywilnego w latach 1919-1989. Zarys problematyki”, Roczniki Nauk Prawnych 23, 2013, no. 1.

Moszyńska A., "Prace nad kodyfikacją majątkowego prawa cywilnego w latach 1950-52", Miscellanea Historico-Iuridica 14, 2015, no. 2.

Moszyńska A., "Work on the Polish Civil Code in Stalinist period (1948-1956)", Právněhistorické Studie 49, 2020, no. 2.

Moszyński R., Policha L., Izdebska A., Księgi wieczyste, Warszawa 1960.

Mróz T., "The role of property law in creating the basis of the market economy after 1989 (regarding the historical context)", Optimum. Economic Studies 2019, no. 4.

Musiał F., "Stalinism in Poland", The Person and the Challenges 9, 2019, no. 2.

Niedośpiał M., "Wprowadzenie do części I", [in:] M. Niedośpiał, B. Wacławik, Prawo własności. Aspekty prawne - etyczne (moralne) - społeczne - filozoficzne - ekonomiczno-finansowe, Warszawa 2013.

Nowakowski Z.K., Prawo rzeczowe. Zarys wyktadu, Warszawa 1980.

Pisuliński J., [in:] Ustawa o księgach wieczystych i hipotece. Postępowanie wieczystoksięgowe, ed. J. Pisuliński, Warszawa 2014.

Projekt prawa rzeczowego uchwalony w pierwszym czytaniu przez Podkomisje Prawa Rzeczowego Komisji Kodyfikacyjnej, Warszawa 1937.

Prus B., "Organizacja struktury ksiąg wieczystych w Polsce”, Infrastruktura i Ekologia Terenów Wiejskich 2011, no. 3.

Radwański Z., "Zielona Księga. Optymalna wizja Kodeksu Cywilnego w Rzeczypospolitej Polskiej”, Ruch Prawniczy, Ekonomiczny i Socjologiczny 2007, no. 1.

Rogacka-Łukasik A., "Jawność ksiąg wieczystych w świetle nowelizacji przepisów w 2013 roku”, Przeglad Ustawodawstwa Gospodarczego 2014, no. 11.

Rudnicki S., "Nowy projekt prawa o księgach wieczystych i hipotece", Nowe Prawo 1968, no. 12.

Rudnicki S., "Systemy ksiąg wieczystych i zabezpieczeń majątkowych na nieruchomościach w większości krajów europejskich", Rejent 1995, no. 11.

Rudnicki S., "Zmiana ustawy o księgach wieczystych i hipotece”, Rejent 2001, no. 10.

Rudzinski A.W., "Sovietization of civil law in Poland", The American Slavic and East European Review 15, 1956, no. 2.

Sadomski J., Zaradkiewicz K., Wybrane zagadnienia reformy wymiaru sprawiedliwości - głos w dyskusji, raport Instytutu Wymiaru Sprawiedliwości no. 51, Warszawa 2005.

Siciński P., "Nowe ujęcie jawności formalnej ksiąg wieczystych", part 1. Nieruchomości 2014, no. 8; part 2. Nieruchomości 2014, no. 9.

Skąpski J., "Funkcja ksiąg wieczystych", [in:] Prace z prawa cywilnego wydane dla uczczenia pracy naukowej Józefa Stanisława Piątowskiego, eds. B. Kordasiewicz, E. Łętowska, Wrocław 1985.

Sławicki P., "Mortgage registers and mortgage council in the Kingdom of Poland", Miscellanea Historico-Iuridica 12, 2013. 
Sokołowski T., "Property law", [in:] Foundations of Law: The Polish Perspective, eds. W. Dajczak, T. Nieborak, P. Wiliński, Warszawa 2021.

Stawecki T., "Rejestry nieruchomości, księgi hipoteczne i księgi wieczyste od czasów najdawniejszych do XXI wieku", Studia Iuridica 40, 2002.

Stawecki T., Rejestry publiczne. Funkcje instytucji, Warszawa 2005.

Stefańska A., Elektroniczna księga wieczysta, Warszawa 2011.

Stelmachowski A., "W kwestii przyszłości ksiąg wieczystych", Nowe Prawo 1964, no. 3.

Szlanta P., Polish Roads to Independence, https://niepodlegla.gov.pl/en/about-niepodlegla/polishroads-to-independence/ (accessed: 27.09.2021).

Szpunar A., „Nowa ustawa o księgach wieczystych i hipotece”, Państwo i Prawo 1983, no. 5.

Szumiło M., Battle of Warsaw 1920, https://ipn.gov.pl/en/digital-resources/articles/4397,Battle-ofWarsaw-1920.html (accessed: 27.09.2021).

Wasilkowski J., "Zagadnienie hipoteki i ksiąg wieczystych w przyszłym prawie cywilnym”, Państwo i Prawo 1955, no. 5.

Wasilkowski J., "Zasady ustroju ksiąg wieczystych w projekcie prawa rzeczowego”, Przegląd Notarialny 1937, no. 13-14.

Wójcikiewicz W., Prawo hipoteczne Królestwa Polskiego, Wrocław 1967.

Zabielski L., "Prowadzenie ksiąg wieczystych i innych rejestrów publicznych. Ocena i kierunki zmian", Nowy Przeglad Notarialny 2001, no. 7-8.

Zaradkiewicz K., "Księga wieczysta i inne publiczne rejestry dóbr prawnych w pracach Komisji Kodyfikacyjnej Prawa Cywilnego", Rejent 2015, no. 5.

Zdziennicki B., "Regulacja prawna ksiąg wieczystych", Studia Prawnicze 2001, no. 2.

Zoll F., Drugi referat przygotowawczy do prac nad skodyfikowaniem jednolitego prawa ksiag ziemskich (ksiag hipotecznych, gruntowych, wieczystych), obejmujacy zestawienie tez, które maja być podstawa projektu ustawy, Warszawa 1931.

Zoll F., Referat przygotowawczy do prac nad skodyfikowaniem jednolitego prawa ksiag ziemskich (ksiag hipotecznych, gruntowych, wieczystych), obejmujacy głównie zarysy projektu ustawy z objaśnieniami, Warszawa 1930. 